\title{
Differences in Graduation and Persistence Rates over Time for African-American Students at Texas 4-Year Universities
}

\author{
By Jerrell Sherman ${ }^{*} \&$ John R. Slate ${ }^{\dagger}$
}

\begin{abstract}
In this study, the graduation and persistence rates of African-American students at Texas 4-year universities were examined for the 2003-2004 academic year, the 2009-2010 academic year, and the 2014-2015 academic year. Of specific interest was whether the graduation and persistence rates for African-American students changed over an 11-year time period in Texas, from 2003-2004 to 2014-2015. Inferential statistical analyses did not reveal the presence of any statistically significant differences in the 1-year graduation and persistence rates of African-American students over the 11-year time period that were investigated. The 1-year graduation and persistence rates were stable, ranging only from $53 \%$ to $56 \%$, over this 11 -year time period. Suggestions for policy and for practice, as well as recommendations for future research, were mentioned.
\end{abstract}

Keywords: African-American, 4-year universities, graduation and persistence rates, interactive accountability system, 1-year persistence rates, Texas.

\section{Introduction}

Institutions of higher education are regularly in search of new ways to attract and maintain a diverse student body comprised of people from different ethnicities/races, backgrounds, and beliefs to heighten the college environment at their institutions. A particular group of students, that colleges and universities have had a challenging time to attracting, retaining, and cultivating are AfricanAmerican students. Moss and Slate (2017) discovered that student enrollment at 4year institutions increased by 65\% between 1992 and 2012. Aud et al. (2011) revealed that the African-American student post baccalaureate enrollment revolved between $10 \%$ and $12 \%$ from 1976 to 2000, and in 2009 around $15 \%$. Weddle-West and Bingham (2010) determined that African-American students have poorer completion rates compared to their White peers in their degree attainment rates, as only $50 \%$ of all students who enroll in a postsecondary institution earn a degree. It is important for African-American students and students of any race/ethnicity to be able to obtain a college degree, as each college graduate can expect lifetime earnings at least two times more than people with only a high school diploma (Carnevale Rose \& Cheah, 2011). To add to the increased need for people in today's society to earn higher education degrees,

*Associate Dean of Students for Judicial Affairs and Student Development, Sam Houston State University, USA.

${ }^{\dagger}$ Full Professor, Sam Houston State University, USA. 
Duncan (2010) stated that throughout the last 40 years, the percentage of occupations in the United States calling for postsecondary degrees has expanded by twice as much.

Before going to college, both African-Americans and Hispanics have faced financial, societal, and cultural issues that have posed challenges, for a large amount at least, pertaining to their approach to and commitment to higher education (Laird et al., 2007). Baum, Ma and Payea (2013) concluded that African American students at $43 \%$ were the ethnic group with the highest college drop-out rates compared to other ethnic/racial groups of students. It is possible that AfricanAmerican students who attend Predominantly White Institutions do not have a sense of belonging to the campus nor have the appropriate resources to be successful, which can be two factors that leads to them dropping out of college (Hunn, 2014). Predominantly White Institutions or PWIs are colleges with student bodies made up mostly of Whites with smaller amounts of other students of different ethnic/racial groups. Historically Black Colleges and Universities or HBCUs are colleges that were founded for the purpose of primarily serving the African-American community prior to the Civil Rights Act of 1964. Researchers (Harper et al., 2004) contended that Historically Black Colleges and Universities have a larger variety of culturally attractive settings for African-American students to participate within the college community. Some researchers (e.g., Bohr, Pascarella, Nora, \& Terenzini, 1995; Chen, Ingram, \& Davis, 2014; Kim, 2002; Seifert, Drummond, \& Pascarella, 2006; Strayhorn \& DeVita, 2010) have suggested however, that African-American students' academic success and gratification with their institution of higher education is contingent on how supportive and inclusive the atmosphere of the campus is toward them, despite it being a HBCU or PWI.

In previous studies pertaining to underrepresented student retention, researchers (Davis, 1994; Simmons, 2017; Strayhorn, 2008) suggested that university's campus culture and environment are major influences of how successful underrepresented students are academically and engage socially at their university. Predominantly White Institutions must create supportive places and spaces for African-American students to feel as if they matter and are welcomed. The aim should be to foster similar foundations of support they would experience attending a HBCU, so students should not be able to tell the differences in the support they receive in acclimating to the campus culture. Creating a campus climate that is all encompassing for their students regardless of their ethnicity/race to support African-American students' success fully should be an important goal for all institutions higher education, not only a goal on which HBCUs should focus on achieving.

Roper (2008) identified that African-American students are greatly affected by college tuition being increased due to many of them coming from low-income families. According to Roper (2008), the average wages for White families in the U.S. was $\$ 60,310, \$ 36,075$ for African-American families, and $\$ 37,387$ for Hispanic families. Gardenhire and Cerna (2016) identified that having positive mentors is another barrier that African-American male students sometimes have a difficult time locating on their college campus and the community in which they 
grew up in. Gardenhire and Cerna (2016) stated that mentoring has the capacity to offer African-American male students with steady support and direction essential to be successful in college; however the authors were clear to acknowledge that it is complicated for colleges to supply this type of assistance. Key aspects identified that are vital to providing a valuable mentorship program involve a good match between mentor and mentee, thorough preparation of mentors, and continuousness contact by the mentor to the mentee. Recommendations made by researchers (Brooms, Goodman, \& Clark, 2015; Laird et al., 2007; Wiggan, 2007; Yearwood $\&$ Jones, 2012) on ways institutions of higher education in general can create atmospheres inside and outside of the classroom for African-American students to engage and persist are: (a) proactive academic advisors and mentors; (b) requesting input from the student body on university policies and campus amenities; (c) having diverse faculty and staff; (d) engaging pedagogy being delivered inside the classroom; (e) enhancement of extracurricular activities, and (f) scholarships to aid students from low-income families.

Institutions of higher education must fully commit to implementing the aforementioned recommendations throughout all levels of leadership at their institutions and make it an engrained mission of the university. University administration cannot rely on faculty and staff diversity committees to host meetings and sponsor sporadic events hoping it will result in minorities at their institutions feeling welcomed and supported by the university (Kuh et al., 2006). All administrators, faculty, staff, and students must genuinely make a concerted effort to make every person at or visitor to their institution regardless of their race, faith, and so on feel as if they belong, are respected, and that the university community is willing to assist them be successful inside and outside of the classroom (Berman, Chaffee, \& Sarmiento, 2018; Milem, Chang, \& Antonio, 2005).

\section{Concepts}

Various policies have been passed and groundbreaking impacts on our society were made by the things such the Civil Rights movement that established the ability for minorities and other underrepresented groups of people to attend college to make sufficient salaries to improve the lives and futures of their families (Ogbu \& Simons, 1998). People aiming to improve their financial and societal place in the world must realize that a simple high school diploma is not suitable as it may have been 20 to 30 years ago. Swail et al. (2003) stated,

Given that the U.S. will become significantly "less White" over the course of the next 50 years, issues of color cannot be ignored. California is already a "majority-minority" state, but its flagship public institutions of higher education have embarrassing low participation rates among AfricanAmerican and Hispanic students. Texas, Florida, and several other states host similar problems. (p. 6) 
Granted, entrance into college has improved, however other concerns have arisen. I $\mathrm{n}$ recent years, admission and retention statistics of underrepresented students have worsened (Beyer et al., 2014). Some parents and high school graduates wonder if institutions of higher education are truly providing the necessary resources required for all students, no matter their ethnicity, to persevere to obtain college degrees (Allen et al., 2008). In addition, colleges and universities boast about having diverse campuses and establishing inclusive atmospheres however, underrepresented college student success rates indicate that large percentages of students of color are not graduating from their institutions. In the past, the need for students of color to be successful in college and in the world, many times were overlooked. However, over time the population of the United States is becoming less White dominant. As such, the underachieving of students of color can no longer be overlooked (Swail et al., 2003).

\section{Significance of the Study}

A substantial number of researchers (e.g., Aud et al., 2011; Ballinger \& Slate, 2017; Chen et al., 2014; Hunn, 2014; Weddle-West \& Bingham, 2010) have mentioned that African-American students do not perform as well academically as their White peers and the direct relationship between academic success and the appropriate resources and campus atmosphere needed for students to be successful in higher education. In addition, an adequate amount of research exists regarding factors regarding the persistence of African-American students. Limited research exists primarily on the graduation and persistence rates of African-American students over time in a particular region or state in America. Moss and Slate (2017) investigated the 1-year persistence rates by institutional enrollment status for African-American students enrolled in Texas community colleges for the 2007-2008 through 2013-2014 academic years. Moss and Slate (2017) established that 1-year persistence rates by institutional enrollment status were better for African-American students who remained at the same Texas community college than for African-American students who transferred to another community college in Texas. The results from this study may provide important information for educational leaders at Texas 4-year universities regarding their efforts in improving the graduation and persistence rates of their African-American students over time.

\section{Purpose of the Study}

The purposes of this study were threefold. The first purpose was to determine the degree to which 1-year graduation and persistence rates differed for AfricanAmerican students enrolled at Texas 4-year public universities in the 2003-2004 through the 2009-2010 academic years. The second purpose was to investigate the degree to which differences were present in the 1-year graduation and persistence rates differed for African-American students enrolled at Texas 4-year public 
universities in the 2009-2010 to the 2014-2015 academic years. The third purpose was to examine if 1-year graduation and persistence rates differed for AfricanAmerican students enrolled at Texas 4-year public universities in the 2003-2004 to the 2014-2015 academic years. By examining multiple years of statistics for each of the Texas 4-year public universities, any trends that existed in the 1-year graduation and persistence rates for African-American students enrolled at Texas 4-year public universities over an 11-year time period were ascertained.

\section{Research Questions}

The following research questions were addressed in this investigation: (a) What is the difference in the graduation and persistence rates of African-American students at Texas 4-year universities between the 2003-2004 academic year and the 2009-2010 academic years?; (b) What is the difference in the graduation and persistence rates of African-American students at Texas 4-year universities between the 2009-2010 academic year and the 2014-2015 academic years?; and (c) What is the difference in the graduation and persistence rates of AfricanAmerican students at Texas 4-year universities between the 2003-2004 academic year and the 2014-2015 academic years?

\section{Method}

\section{Research Design}

In this study a non-experimental, causal-comparative research design was utilized (Creswell, 2013). For this multiyear examination, archival data from the Texas Higher Education Coordinating Board were obtained and analyzed. The independent variable and the dependent variables previously happened. The independent variable in this study was the academic years of 2003-2004, 20092010, and 2014-2015. The dependent variables were the 1-year graduation and persistence rates of African-American students enrolled in Texas 4-year public universities. Utilization of archival data in this context established a causal comparative research design (Creswell, 2013).

\section{Participants and Instrumentation}

The archival data for this study were obtained from the Texas Higher Education Coordinating Board Interactive Accountability System database. The Texas Higher Education Coordinating Board encourages entry to and achievement in quality higher education throughout the state of Texas (Texas Higher Education Coordinating Board, 2016b). The Texas Higher Education Coordinating Board Interactive Accountability System is an openly available archive that follows the performance of vital assessments that embody the objectives of institutions of higher education (Texas Higher Education Coordinating Board, 2016a). Existing 
data on the website were retrieved and saved using Microsoft Excel and then recoded into SPSS format for statistical examination. African-American students attending 4-year Texas public universities in Texas were the participants who were enrolled during the 2003-2004, 2009-2010, and the 2014-2015 academic years.

Each of these 4-year universities is mandated by the Texas Higher Education Coordinating Board to report the 1-year graduation and persistence rates, containing with other information, of students by ethnic group/race. Data turned in are then accumulated by the Texas Higher Education Coordinating Board and made openly accessible at the Texas Higher Education Coordinating Board Interactive Accountability System. The databases utilized for this investigation was the Texas Higher Education Coordinating Board Interactive Accountability archive. The Texas Higher Education Coordinating Board upholds a massive archive encompassing statistics for every 4-year university in Texas. Contained within these statistics are graduation and persistence rates of African-American students. In the 2003-2004 academic year, 30 Texas 4-year universities supplied statistics. For the 2009-2010 academic year, 30 Texas 4-year universities supplied statistics. Finally, during the 2014-2015 academic year, statistics were available from 31 Texas 4-year universities.

\section{Results}

Before performing inferential statistics to ascertain if differences existed in the 1-year graduation and persistence rates of African-American students attending Texas 4-year universities, the standardized skewness coefficients (i.e. the skewness value divided by the standard error of skewness) and the standardized kurtosis coefficients (i.e., the kurtosis value divided by the standard error of kurtosis) were calculated. Because the dependent variable, graduation and persistence rates, was a continuous variable, and due to the independent variable representing the academic years of data that were evaluated, the second and third assumptions for a parametric dependent samples $t$-test were met; for that reason, a parametric dependent samples $t$-test was performed for research questions one, two, and three (Onwuegbuzie \& Daniel, 2002).

A parametric dependent samples $t$-test did not reveal a statistically significant difference in the graduation and persistence rates, $t(29)=-0.21, p=.84$, between the 2003-2004 academic year and the 2009-2010 academic years. The graduation and persistence rates were in the mid-50s range for African-American students who attended Texas 4-year universities in the 2003-2004 academic year and in the 2009-2010 academic year. Over this 6-year time period, the graduation and persistence rates of African-American students remained stable at slightly over $50 \%$. Readers are directed to Table 1 for the descriptive statistics for this analysis. 
Table 1. Descriptive Statistics for Graduation and Persistence Rates of AfricanAmerican Student Enrolled at Texas 4-Year Universities during the 2003-2004 and 2009-2010 Academic Years

\begin{tabular}{|l|c|c|c|}
\hline Academic Year & $\boldsymbol{n}$ of 4-Year Universities & $\boldsymbol{M \%}$ & $\boldsymbol{S} \boldsymbol{\%}$ \\
\hline $2003-2004$ & 30 & 55.49 & 19.52 \\
\hline $2009-2010$ & 30 & 55.89 & 21.59 \\
\hline
\end{tabular}

Regarding the 2009-2010 and the 2014-2015 academic years, the parametric dependent samples $t$-test did not yield a statistically significant difference in the graduation and persistence rates, $t(30)=-0.80, p=.43$, of African-American at 4year Texas universities. The 1-year graduation and persistence rates were in the low to mid-50s range for African-American students who attended Texas 4-year universities in the 2009-2010 academic year and in the 2014-2015 academic year. Table 2 contains the descriptive statistics for this examination.

Table 2. Descriptive Statistics for Graduation and Persistence Rates of AfricanAmerican Student Enrolled at Texas 4-Year Universities during the 2009-2010 and 2014-2015 Academic Years

\begin{tabular}{|l|c|c|c|}
\hline Academic Year & $\boldsymbol{n}$ of 4-Year Universities & $\boldsymbol{M \%}$ & $\boldsymbol{S D \%}$ \\
\hline $2009-2010$ & 31 & 52.69 & 20.28 \\
\hline $2014-2015$ & 31 & 55.91 & 16.80 \\
\hline
\end{tabular}

With respect to the 2003-2004 and the 2014-2015 academic years, the parametric dependent samples $t$-test did not reveal a statistically significant difference in the 1-year persistence rates, $t(29)=0.30, p=.76$, among AfricanAmerican students' graduation and persistence rates at 4-year Texas universities. The 1-year graduation and persistence rates were the mid-50s range for AfricanAmerican students who attended Texas 4-year universities in the 2003-2004 academic year and in the 2014-2015 academic year. Revealed in Table 3 are the descriptive statistics for this assessment.

Table 3. Descriptive Statistics for Graduation and Persistence Rates of AfricanAmerican Student Enrolled at Texas 4-Year Universities during the 2003-2004 and 2014-2015 Academic Years

\begin{tabular}{|l|c|c|c|}
\hline Academic Year & $\boldsymbol{n}$ of 4-Year Universities & $\boldsymbol{M \%}$ & $\boldsymbol{S} \boldsymbol{\%}$ \\
\hline $2003-2004$ & 30 & 55.49 & 19.52 \\
\hline $2014-2015$ & 30 & 54.45 & 14.93 \\
\hline
\end{tabular}

\section{Discussion}

In this examination, the degree to which differences were present in the 1-year graduation and persistence rates for three academic years for African-American students enrolled at Texas 4-year universities was assessed. Three different academic years of data from the Texas Higher Education Coordinating Board Interactive Accountability System were attained and assessed to ascertain if differences were present in 1-year graduation and persistence rates of African- 
American students attending Texas 4-year universities. For the three years of academic data that were analyzed, statistically significant differences were not present. The 1-year graduation and persistence rates of African-American students who attended Texas 4-year universities were remarkably stable over time as they ranged from a low of $53 \%$ to a high of $56 \%$.

\section{Connections with the Existing Literature}

Within this multiyear, statewide examination, the 1-year graduation and persistence rates of African-American students attending Texas 4-year universities were not statistically significantly higher when comparing African-American student enrolled at Texas 4-year universities five to 10 years apart. These results were compatible with Moss and Slate's (2017) results on the 1-year persistence rates of African-American community college students in Texas during the 20112012 and 2012-2013 academic years and Ballinger and Slate (2017) who also investigated 1-year persistence rates at Texas 4-year public universities. Population projections reflect that the numbers of underrepresented high school graduates will continue to increase in the future (Swail, Reed, \& Perna, 2003). Sadly, as demonstrated in this study and in present research (Aud et al., 2011; Baum et al., 2013; Moss \& Slate, 2015), graduation and persistence rates have been unsatisfactory for a very long period of time for African-American students.

\section{Implications for Policy and for Practice}

Formed on the outcomes of this multiyear analysis, numerous implications exist for policy and for practice. To understand how to attract and maintain African-American students at Texas 4-year universities and state universities in general, research can be completed regarding HBCUs recruit and nurture their students. Researchers (e.g., Harper et al., 2004) concluded from their completed research that HBCUs have a broader range of culturally attractive settings for African-American students to participate within the college community. Several researchers (e.g., Bohr et al., 1995; Chen et al., 2014; Kim, 2002; Seifert et al., 2006; Strayhorn \& DeVita, 2010) have pointed out however, that AfricanAmerican students' academic success and gratification with their institution of higher education is contingent on how supportive and inclusive the atmosphere of the campus is towards them despite it being a Historically Black College and University or Predominantly White Institution.

Recommendations made by previous researchers on ways institutions of higher education in general can create atmospheres inside and outside of the classroom for African-American students to engage and persist are: (a) proactive academic advisors and mentors; (b) requesting input from the student body on university policies and campus amenities; (c) having diverse faculty and staff; (d) engaging pedagogy being delivered inside the classroom; (e) enhancement of extracurricular activities, and (f) scholarships to aid students from low-income families (Brooms, Goodman, \& Clark, 2015; Laird et al., 2007; Wiggan, 2008; Yearwood \& Jones, 2012). 
African-American students must have supportive social and support systems, particularly at Predominantly White Institutions. Student organizations such as culturally based organizations, Greek organizations, honors societies, and other common interest student organizations can be an important support system for African-American students (Allen, 1992; Doan, 2011; Guiffrida, 2003; Harper, 2007; Simmons, 2017). Black Greek organizations hold their members to high standards such as GPA minimum requirements, leadership training, mandatory community service and philanthropy projects, hosting activities and events for the African-American community at the university, along with being urged to be a positive example for other African-American students at the university (Harper, 2007; Harper \& Harris, 2006; Harper \& Quaye, 2007; Hughey, 2007; Pascarella et al., 1996).

The confidence and skills which African-American students and other students of color gain from membership in student organizations give them the coping skills and motivation to be successful in school to go on and be productive in life. Engstrom and Tinto (2008) stated that, "Access without support is not opportunity" (p. 10). It is in the spirit of his statement and the fact that the United States will only continue to grow to be more diverse that institutions of higher education should do all in their power increase access to and buildup retention amid at-risk underrepresented student populaces.

\section{Conclusion}

In this quantitative study, the 1-year graduation and persistence rates of AfricanAmerican students at Texas 4-year public universities were assessed. As a result, numerous suggestions can be formed for future investigations. Foremost, investigators are urged to extend this study to other states to ascertain the degree to which our results might be generalizable to other states. Next, investigators are encouraged to assess 1-year graduation and persistence rates for other ethnic/racial groups of students (e.g., Asian, White, Hispanic). Another recommendation for future research would be to ascertain whether differences are present for underrepresented students by their gender with respect to their 1-year graduation and persistence rates. Further, investigators are urged to analyze to analyze their 1year persistence rates of English Language Learners in states with a sufficient number of them. Lastly, investigators are urged to broaden this study to Texas community colleges. The degree to which results based on 4-year university students are generalizable to community college students is not known.

\section{References}

Allen, W.R. (1992). The color of success: African-American college student outcomes at predominantly White and historically Black public colleges and universities. Harvard Educational Review, 62(1), 26-44. doi:10.17763/haer.62.1.wv56276650 07v701. 
Allen, J., Robbins, S., Casilla, A., \& Oh, I. (2008). Third-year college retention and transfer: Effects of academic performance, motivation, and social connectedness. Research in Higher Education, 49, 647-664. doi:10.1007/s11162-008-9098-3.

Aud, S., Hussar, W., Kena, G., Bianco, K., Frohlich, L., Kemp, J., \& Tahan, K. (2011). The Condition of Education 2011 (NCES 2011-033). Washington, DC: US Government Printing Office. National Center for Education Statistics, US Department of Education. Retrieved from: http://nces.ed.gov.

Baum, S., Ma, J., \& Payea, K. (2013). Education pays 2013: The benefits of higher education for individuals and society. The College Board. Retrieved from https://bit.ly/2rwjOm5.

Ballinger, R., \& Slate, J.R. (2017). Ethnic/racial differences in 1-year persistence rates by institutional status at Texas 4-year universities over time. Journal of Advances in Education Research, 2(4), 280-286. doi:10.22606/jaer.2017.24008

Berman, S., Chaffee, S., \& Sarmiento, J. (2018). The practice base for how we learn: Supporting students' social, emotional, and academic development. The Aspen Institute. Retrieved from https://bit.ly/370xgxu.

Beyer, C., Davis-Unger, A., Lowell, N., Mcghee, D., \& Peterson, J. (2014). University of Washington undergraduate retention and graduation study. Retrieved from https://bit.ly/2R3yyDx.

Bohr, L., Pascarella, E.T., Nora, A., \& Terenzini, P.T. (1995). Do Black students learn more at historically Black or predominantly White colleges? Journal of College Student Development. 36(1), 75-85. Retrieved from https://bit.ly/2L 7hxF0.

Brooms, D.R., Goodman, J., \& Clark, J. (2015). "We need more of this": Engaging Black men on college campuses. College Student Affairs Journal, 33(1), 105-123. doi:10.1353/csj.2015.0002.

Carnevale, A.P., Rose, S., \& Cheah, B. (2011). The college payoff: Education, occupation, and lifetime earnings. Washington, DC: Georgetown University, Center on Education and the Workforce. Retrieved from https://bit.ly/2XVGeJu.

Chen, P.D., Ingram, T.N., \& Davis, L.K. (2014). Bridging student engagement and satisfaction: A comparison between historically Black colleges and universities and predominantly White institutions. The Journal of Negro Education, 83(4), 565-579. doi:10.7709/jnegroeducation.83.4.0565.

Creswell, J.W. (2013). Research design: Qualitative, quantitative, and mixed methods approaches $\left(4^{\text {th }}\right.$ ed.). Thousand Oaks, CA: Sage.

Davis, J.E. (1994). College in Black and White: Campus environment and academic achievement of African-American males. The Journal of Negro Education, 63(4), 620-633. doi:10.2307/2967299.

Doan, J. (2011). The impact of campus climate and student involvement on students of color. The Vermont Connection, 32(1), 4. Retrieved from https://bit.ly/34wxDQ6.

Duncan, A. (2010). Back to school: Enhancing U.S. education and competitiveness. Foreign Affairs, 89(6), 65-74. Retrieved from https://fam.ag/2L4nVwO.

Engstrom, C., \& Tinto, V. (2008). Access without support is not opportunity. Change: The magazine of higher learning, 40(1), 46-50. doi:10.3200/CHNG.40.1.46-50.

Gardenhire, A., \& Cerna, O. (2016). Boosting college success among men of color: Promising approaches and next steps. Research Brief. MDRC. Retrieved from https://bit.ly/33yaL1g.

Guiffrida, D.A. (2003). African-American student organizations as agents of social integration. Journal of College Student Development, 44(3), 304-319. doi:10.13 53/csd.2003.0024. 
Harper, S.R. (2007). Peer support for African-American male college achievement: Beyond internalized racism and the burden of "acting White". The Journal of Men's Studies, 14(3), 337-358. Retrieved from https://bit.ly/37PjmuW.

Harper, S.R., \& Harris III, F. (2006). The role of Black fraternities in the AfricanAmerican male undergraduate experience. In M. J. Cuyjet (Ed.), African-American men in college (pp. 128-153). San Francisco, CA: Jossey-Bass.

Harper, S.R., \& Quaye, S.J. (2007). Student organizations as venues for Black identity expression and development among African-American male student leaders. Journal of College Student Development, 48(2), 127-144.

Harper, S.R., Carini, R.M., Bridges, B.K., \& Hayek, J.C. (2004). Gender differences in student engagement among African-American undergraduates at historically Black colleges and universities. Journal of College Student Development, 45(3), 271-284. doi:10.1353/csd.2004.0035.

Hughey, M.W. (2007). Crossing the sands, crossing the color line: Non-Black members of Black Greek letter organizations. Journal of African-American Studies, 11(1), 55-75. doi:10.1007/s12111-007-9002-9.

Hunn, V. (2014). African American students, retention, and team-based learning: A review of the literature and recommendations for retention at predominantly White institutions. Journal of Black Studies, 45(4), 301-314. doi:10.1177/0021934 714529594.

Kim, M.M. (2002). Historically Black vs. White institutions: Academic development among Black students. The Review of Higher Education, 25(4), 385-407. Retrieved from https://bit.ly/33oGsdq.

Kuh, G.D., Kinzie, J., Cruce, T., Shoup, R., \& Gonyea, R.M. (2006). Connecting the dots: Multi-faceted analyses of the relationships between student engagement results from the NSSE, and the institutional practices and conditions that foster student success. Bloomington, IN: Indiana University, Bloomington, Center for Postsecondary Research.

Laird, T., Bridges, B., Morelon-Quainoo, C., Williams, J., \& Salinas Homes, M. (2007). African American and Hispanic student engagement at minority serving and predominantly White institutions. Journal of College Student Development, 48(1), 39-56.

Milem, J.F., Chang, M.J., \& Antonio, A.L. (2005). Making diversity work on campus: A research-based perspective. Washington, DC: American Association of Colleges and Universities. Retrieved from https://bit.ly/35UgS1J.

Moss, S., \& Slate, J.R. (2017). Differences in the 1-year persistence rates by student institutional status for Black students at Texas community colleges: A statewide multiyear investigation. AASCIT Journal of Psychology, 3(3), 25-33. Retrieved from https://bit.ly/33wsGFJ.

Ogbu, J.U., \& Simons, H.D. (1998). Voluntary and involuntary minorities: A cultural ecological theory of school performance with some implications for education. Anthropology \& Education Quarterly, 29(2), 155-188.

Onwuegbuzie, A.J., \& Daniel, L.G. (2002). Uses and misuses of the correlation coefficient. Research in the Schools, 9(1), 73-90.

Pascarella, E.T., Edison, M., Whitt, E.J., Nora, A., Hagedorn, L.S., \& Terenzini, P.T. (1996). Cognitive effects of Greek affiliation during the first year of college. NASPA Journal, 33, 242-259.

Roper, C.G. (2008). Financing the American dream: Negative effects of financial aid policy on student enrollment. (CHHC Policy Report, February 2008, No. 1) Clemson, SC: Clemson University, Eugene T. Moore School of Education, Charles H. Houston 
Center for the Study of the Black Experience in Education. Retrieved from https://bit.ly/2XWIZdH.

Seifert, T.A., Drummond, J., \& Pascarella, E.T. (2006). African-American students' experiences of good practices: A comparison of institutional type. Journal of College Student Development, 47(2), 185-205. Retrieved from https://bit.ly/ 2L52Dik.

Simmons, L.D. (2017). Beyond matriculation: Examining factors that contribute to African American male persistence at a predominantly White institution. Journal of College Student Retention: Research, Theory \& Practice. doi:10.1177/152 1025117714163.

Strayhorn, T.L. (2008). The role of supportive relationships in facilitating AfricanAmerican males' success in college. NASPA Journal, 45(1), 26-48. doi:10.2202/ 1949-6605.1906.

Strayhorn, T.L., \& DeVita, J.M. (2010). African-American males' student engagement: A comparison of good practices by institutional type. Journal of African-American Studies, 14(1), 87-105. doi:10.1007/s12111-009-9110-9.

Swail, W., Reed, K., \& Perna, L. (2003). Retaining minority students in higher education, vol. 30. Los Angeles, CA: Ashe Eric. Retrieved from https://bit.ly/2pXiQPg.

Texas Higher Education Coordinating Board. (2016a). Accountability section. Retrieved from https://bit.ly/2XYDLOo.

Texas Higher Education Coordinating Board. (2016b). Agency information. Retrieved from https://bit.ly/2ryVhNe.

Weddle-West, K., \& Bingham, R.P. (2010). Enhancing recruitment, persistence and graduation rates of students of color from P-22: The roles of senior administrators in higher education. National Forum of Applied Educational Research Journal, 24(1), 7-20.

Wiggan, G. (2008). From opposition to engagement: Lessons from high achieving African American students. The Urban Review, 40(4), 317-349. doi:10.1007/s11256-0070067-5.

Yearwood, T.L., \& Jones, E.A. (2012). Understanding what influences successful Black commuter students' engagement in college. JGE: Journal of General Education, 61(2), 97-125. Retrieved from https://bit.ly/2DrPBr5. 